\title{
Zinc Solubilizing Rhizobacteria Associated with Sugarcane from South Gujarat Region
}

\author{
Kajal Ghevariya ${ }^{1}$, Pratibha Desai ${ }^{2}$ \\ Department of Microbiology, Shree Ramkrishna Institute of Computer Education and Applied Sciences, \\ Veer Narmad South Gujarat University, Surat-395001. Gujarat. India
}

\begin{abstract}
Zinc is a one of the eight essential micronutrients required for the normal healthy growth and reproduction of crop plants. Zinc deficiency in an agricultural soil is well-studied and wide spread problem worldwide. This study on zinc solubilization by bacteria has an immense importance in zinc nutrition to plant particularly in fields having alkaline soils as observed in present study. Among 309 isolates, 141 isolates were positive for zinc solubilization. Considering the quantitative aspects solubilization efficiency of bacterial isolates was ranged from (116-366) for 0.1\% zinc oxide incorporated in the medium. Based on solubilization efficiency five isolates with highest $\mathrm{Zn}$ solubilization efficiency were chosen for multiple plant growth promoting traits from which BM/F1/ER/8, NFM/F2/RP/15, and $\mathrm{KBM} / \mathrm{F} / \mathrm{RH} / 5$ have multiple plant growth promoting traits can be exploited as a potential biofertilizers.
\end{abstract}

Keywords: Zinc solubilization, Zinc oxide, Biofertilizer.

\section{Introduction}

The use of microorganisms with the aim of improving nutrients availability for plants is an important practice and necessary for agriculture (Freitas et al., 2007). Rhizosphere is the place where very important and intensive interactions take place between plants, soil, microorganisms and soil micro fauna, influenced by compounds exuded by roots, and microorganisms feeding on its compounds (Antoun and Prevost, 2006)

In eukaryotic and prokaryotic organisms, the role of Zinc in the nutrition, physiology and especially its importance for activity of many enzymes is widely studied (Hughes and Poole, 1989; Clarke and Berg, 1998). Few zinc solubilizing viz, Thiobacillus thioxidans, Thiobacillus ferroxidans, Acinetobacter, Bacillus, Glucanoacetobacter, Pseudomonas and facultative thermophilic iron oxidizers have been reported as a zinc solubilizers (Saravanan et al., 2007). 50\% of agricultural soils contain low level of available zinc, mainly due to high soil $\mathrm{pH}$, low soil moisture and low organic matter ( Alloway, 2008; Cakmak 2008). Root cell membrane permeability is increased under $\mathrm{Zn}$ deficiency, which might be related to the function of $\mathrm{Zn}$ in cell membranes (Parker et al., 1992). Exogenous application of zinc fertilizer has been applied to various crops and this causes transformation of about 96-99 percent of applied available zinc to various unavailable forms. This unavailable zinc can be reverted back to available form by inoculating a bacterial strain capable of zinc solubilizing potential (Saravanan et al., 2003). Fixation of zinc in soil with $\mathrm{pH}>$ 7.0 increseases with increasing concentration of carbonates and thus become unavailable form with $\mathrm{Zn}$ solubilizing microorganism ( Shahad and Ahmed, 2008). Since zinc is a limiting factor in crop production in alkaline soils of the world. This study on zinc solubilization by bacteria has an immense importance in zinc nutrition to plant particularly in fields having alkaline soils as possible future potential bioinoculants.

\section{Material and Methods}

\section{Sample Collection}

The root adhering samples of five sugarcane plants were collected from the agricultural field of Kamrej, Abrama, Chalthan and Maroli, India. The sample were collected in aseptic bags and immediately transported to lab for further process (Zarrin et al., 2009).

\section{Isolation of Rhizobacteria and Endophytes}

The isolation of rhizobacteria, were carried out from bulk soil, rhizospheric soil, rhizoplane and endorhizospheric sites using $100 \mu \mathrm{L}$ of diluted suspension from each sites were spreaded on different media viz. king's B medium (KBM), ashby's mannitol agar (AMA), nitrogen free medium(NFM), yeast extract mannitol agar (YMA), azospirillum medium (AZ), pikovskaya medium (PM), bacillus medium(BM).

\section{Zinc solubilization assay}

Zinc solubilization assay was performed for all isolates on to the modified Pikovskaya medium (Pikovskaya, 1948) containing $0.1 \%$ insoluble zinc compound (ZNO). All the plates were incubated for $48 \mathrm{~h}$ at $28^{\circ} \mathrm{C}$. Further the Zinc solubilization efficiency (SE) of the isolates was calculated and determined as mentioned by Ramesh et al., (2014) SE = Diameter of solubilization halo zone / diameter of colony $\times \mathbf{1 0 0}$

\section{Result and Discussion}

Zinc solubilization has been studied and evaluated nearly in crop plants like cereals (cakmak, 2008) Maize ( Shruthi P., 2013, Preveen kumar et al., 2013), Soybean (Poonam S. et al.,2014). While comparing all the four locations, the Maroli field has a highest number of isolates (85) from all the sites. The rhizospheric soil has highest number of isolates compare to rhizoplane and endorhizosphere (Fig.1). Reyes et $a l ., 2006$ have also reported that rhizospheric soil possesses higher number of bacteria as compared to non-rhizospheric soil. Which prove the necessity of bacteria for solubilization of nutrients present in bulk soil and make it available in more amounts in rhizospheric soil and finally available to 


\section{International Journal of Science and Research (IJSR) \\ ISSN (Online): 2319-7064 \\ Index Copernicus Value (2013): 6.14 | Impact Factor (2014): 5.611}

the plant at rhizoplane and endorhizoshere for more physiological activities. In the present study role of bacteria in zinc solubilizing activity have been studied where more number of such isolates found from Maroli field with alkaline soil. This is in agreement with the finding of
(Azadeh B.et al., 2012) who finds the zinc solubilizing potential by fluorescent Pseudomonads from the alkaline soil.

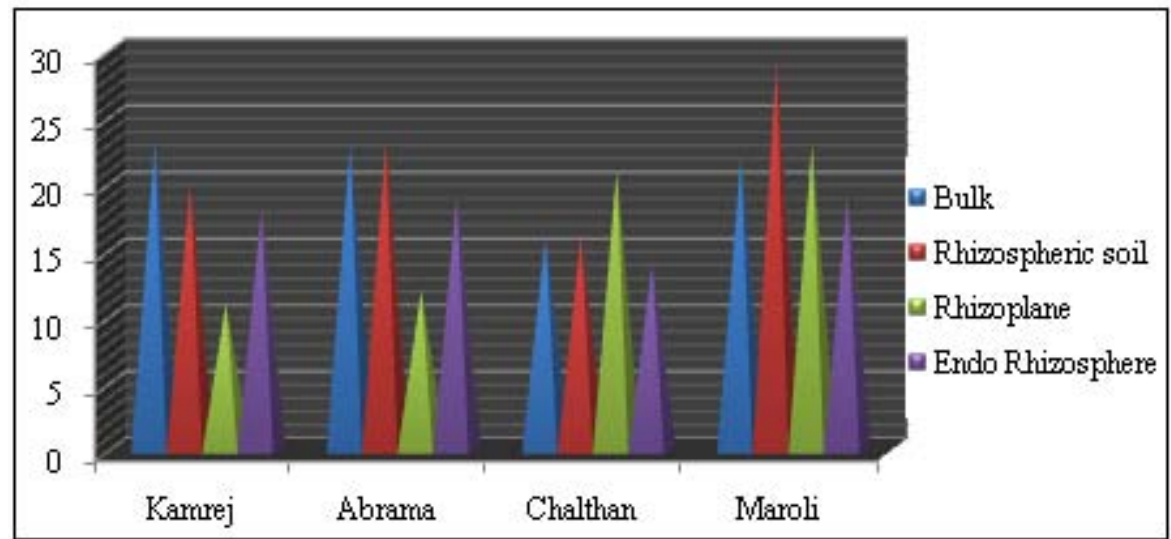

Figure 1: Total No. of isolates from diverse sites.

Zinc is an important micronutrient required for many enzymatic activities by bacteria as well as plant. Plant cannot solubilize zinc, which is solubilize by plant growth promoting bacteria present in soil as well as endophytes in root. As mention above such isolates are found at Maroli field and in particular from site of rhizoplane (Fig.3) which support the role of bacteria and supplying such trace elements after solubization to the plant for the growth.

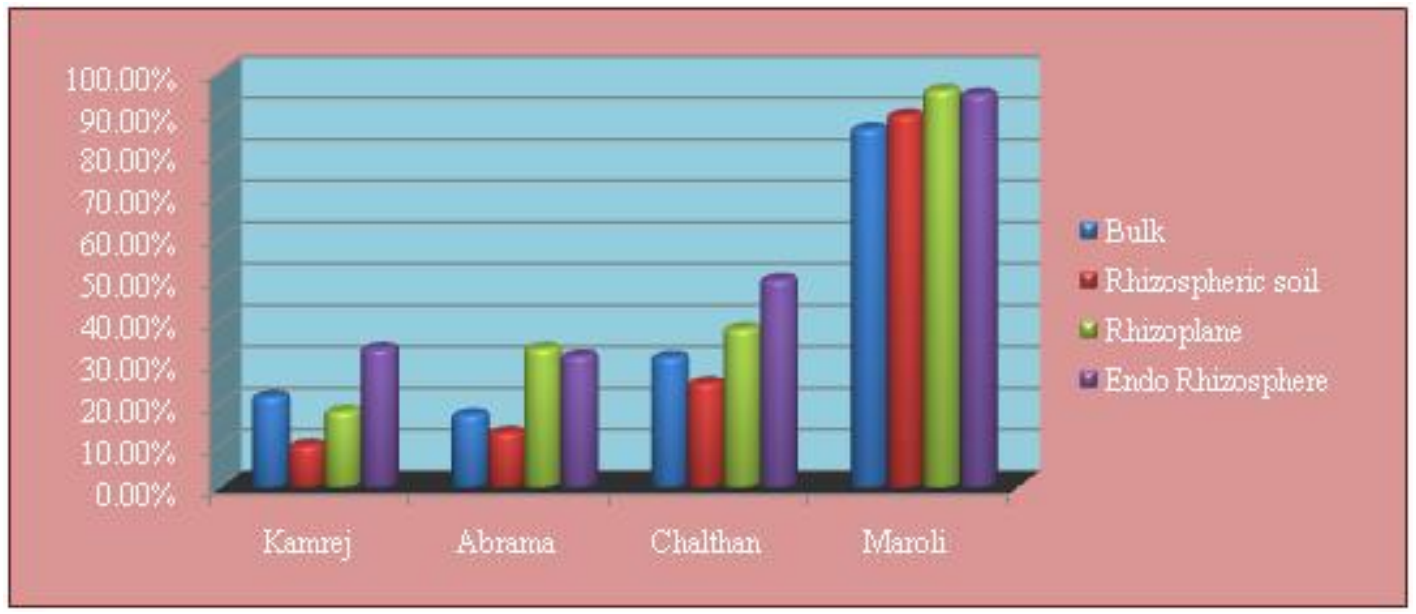

Figure 2: Zinc solibilizing isolates from South Gujarat region

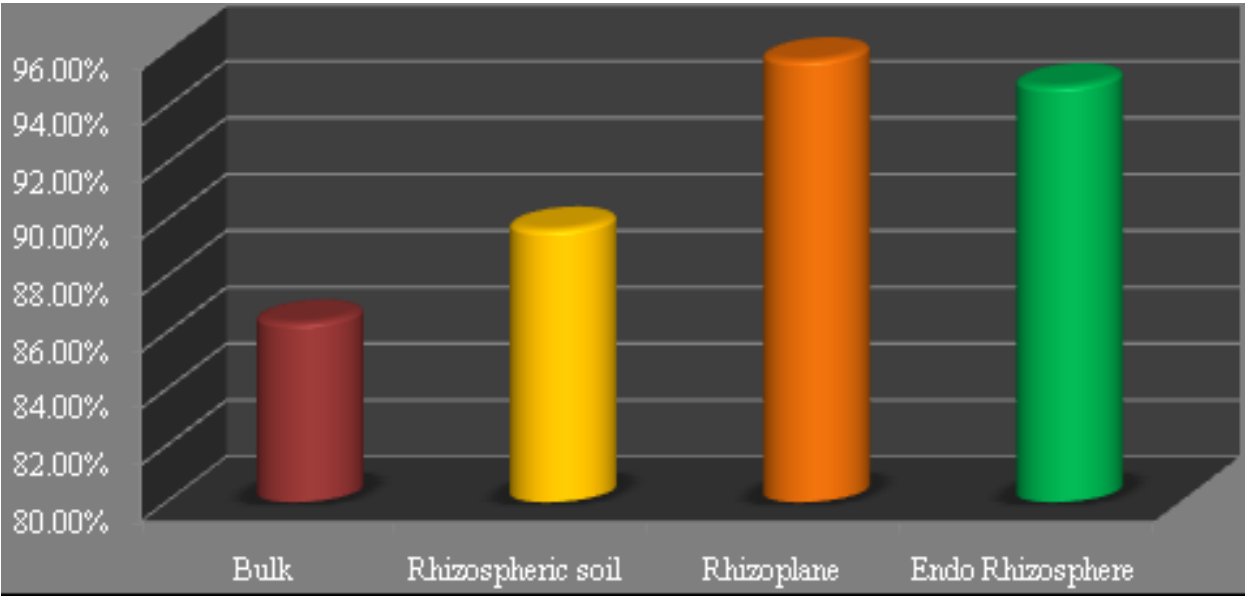

Figure 3: Zinc solibilizing isolates from diverse site of plant 


\section{International Journal of Science and Research (IJSR) \\ ISSN (Online): 2319-7064 \\ Index Copernicus Value (2013): 6.14 | Impact Factor (2014): 5.611}

In plate assay, all positive isolates were subjected to measure the magnitude of $\mathrm{Zn}$ solubilization with zinc oxide as an inorganic source of zinc. Total of 309 isolates 141 isolates were positive for zinc solubilization. Solubilization efficiency of bacterial isolates were ranged from (116-366) for zinc oxide incorporated in the medium. Of the 141 bacterial isolates $9.92 \%$ categorized with highest $\mathrm{Zn}$ solubilization efficiency $(>300)$ whereas $33.33 \%$ were medium range Zn solubilizers (200-300) (Fig.4). Similar to our study, Poonam et al., (2014) had observed zinc solubilization efficiency of bacterial isolates from legume rhizosphere were ranged from (117.2-466) for zinc oxide incorporated in the medium and $11 \%$ categorized with highest $\mathrm{Zn}$ solubilization efficiency and $50 \%$ were medium range $\mathrm{Zn}$ solubilizers. Bacterial isolates produce a halo zone around the bacterial colony which indicated solubilization of zinc oxide in fig. 5 .

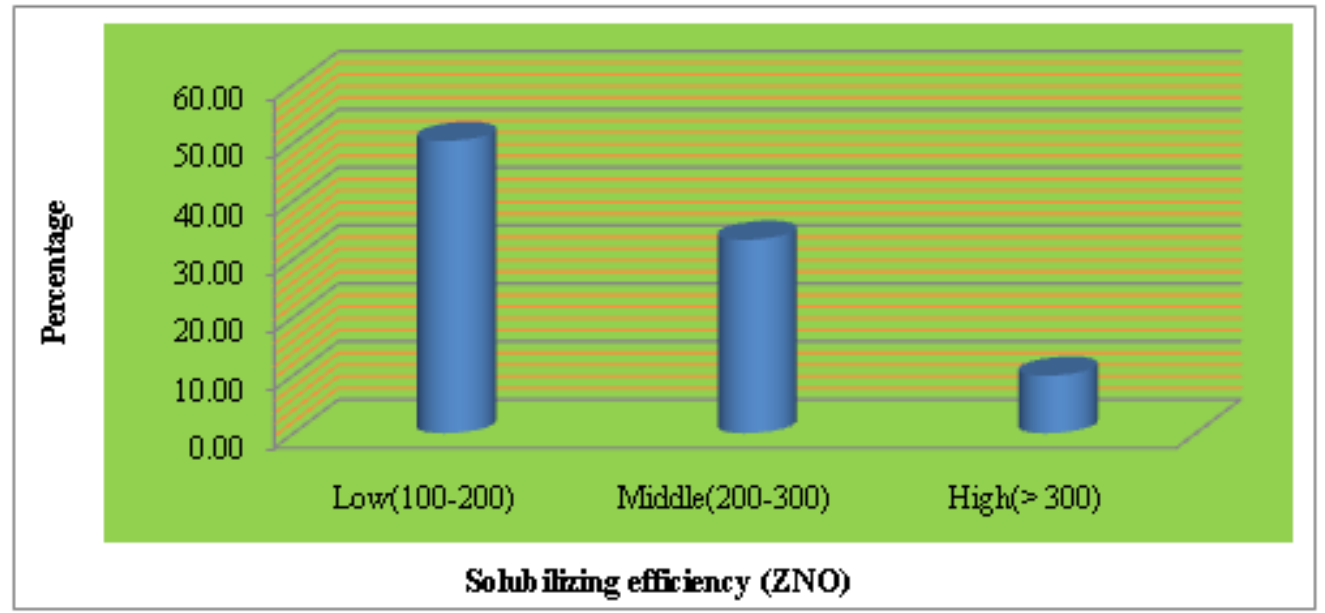

Figure 4: Percentage range of zinc solubilizing efficiency of bacterial isolates
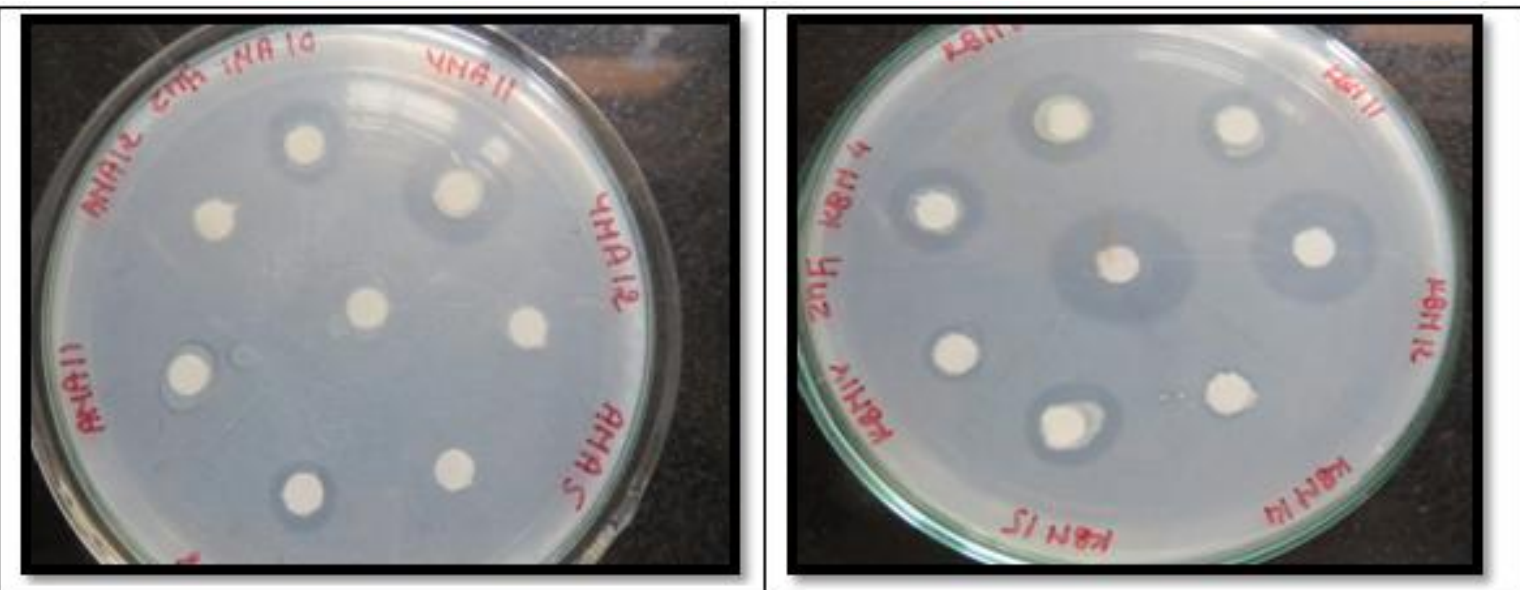

Figure 5: Formation of clear halo zone around bacterial colony

Table 1: Multiple plant growth promoting traits of maximum zinc solubilizing efficiency

\begin{tabular}{|c|c|c|c|c|c|}
\hline $\begin{array}{c}\text { S. } \\
\text { No. }\end{array}$ & Isolate No. & $\begin{array}{c}\text { Phosphate } \\
\text { solubilizing bacteria }\end{array}$ & $\begin{array}{c}\text { Potassium solubilizing } \\
\text { bacteria }\end{array}$ & $\begin{array}{c}\text { Zinc solubilizing } \\
\text { bacteria }\end{array}$ & $\begin{array}{c}\text { Nitrogen fixing } \\
\text { bacteria }\end{array}$ \\
\hline 1 & $\mathrm{AZ} / \mathrm{F} 1 / \mathrm{ER} / 3$ & - & - & ++++ & ++ \\
\hline 2 & $\mathrm{BM} / \mathrm{F} 1 / \mathrm{ER} / 8$ & +++ & ++ & ++++ & + \\
\hline 3 & $\mathrm{NFM} / \mathrm{F} 2 / \mathrm{RP} / 15$ & ++++ & +++ & ++++ & + \\
\hline 4 & $\mathrm{KBM} / \mathrm{F} 4 / \mathrm{RH} / 5$ & ++++ & +++ & +++ & + \\
\hline 5 & $\mathrm{PM} / \mathrm{F} 4 / \mathrm{RH} / 7$ & - & ++ & + \\
\hline
\end{tabular}

Based on solubilization efficiency five isolates (Table 1.) with highest $\mathrm{Zn}$ solubilization efficiency (366) were chosen for multiple plant growth promoting traits viz. Nitrogen fixation, Phosphate solubilization, Potassium solubilization and Zinc solubilization, from which 3 isolates having maximum positive plant growth promoting potentials.

\section{Conclusion}

Based on present study highest Zn solubilization efficiency of bacterial isolates were chosen for multiple plant growth promoting traits, from which $\mathrm{BM} / \mathrm{F} 1 / \mathrm{ER} / 8, \mathrm{NFM} / \mathrm{F} 2 / \mathrm{RP} / 15$, and $\mathrm{KBM} / \mathrm{F} 4 / \mathrm{RH} / 5$ have highest positive plant growth promoting potentials. Such combined inoculation of zinc solubilizing bacterial cultures can be further explores as effective bio-inoculants as they possess a multiple positive 


\section{International Journal of Science and Research (IJSR) \\ ISSN (Online): 2319-7064}

Index Copernicus Value (2013): 6.14 | Impact Factor (2014): 5.611

traits useful for improving plant productivity for substituting chemical fertilizers and also to correct nutrient deficiency in sugarcane for sustainable agriculture.

\section{Acknowledgement}

This work was supported by the Department of Microbiology, Shree Ramkrishna Institute of Computer Education and Applied Sciences, Surat, Gujarat, India. We are thankful to the Director, Management and staff member for supporting this study.

\section{References}

[1] Alloway BJ,(2008), Zinc in soils and crop nutrition. $2^{\text {nd }}$ ed. IZA and IFA, Brussels, p,139.

[2] Antoun H, Prevost D (2006) Ecology of plant growth promoting rhizobacteria. In: Siddiqui ZA (ed) PGPR: biocontrol and biofertilization. Springer, Dordrecht, pp1-38

[3] Azahad B., Ahmad A., Hesam M., Kazem K., Ebrahim P.,2012. Evaluation of Zinc solubilisation potential by different strains of Fluorescent Pseudomonads. J. Appl. Sci.Environ.Manage.vol.16 (3)295-298.

[4] Cakmak I (2008) Enrichment of cereal grains with zinc: agronomic or genetic biofertification? Plant Soil 302:117

[5] Clarke, ND; Berg, JM (1998). Zinc fingers in Caenorhabditisn elegans : finding families and probing pathways. Science 282. 2018-2022. Claverys J-P. 2001 A new family of high affinity $\mathrm{ABC}$ manganese and zinc permeases. Res Microbiol 152: 231-243.

[6] Freitas ADS, Vieira CL, Santos CERS, Stampford NP, Lyra MCCP(2007) Caracterizacao de rizobios isolados de Jacatupe cultivado em solo salino no Estado de permanbuco, Brasil. Bragantia 66:497-504.

[7] Hughes, MN; Pool RK (1989). Metals and Microorganisms. Cnapman and Hall, Londan, p412.

[8] Parisi, B; Vallee, BL (1969). Metal enzyme complexes activated by zinc. J Biol Chem 179: 803-807.

[9] Parker DR, Aguilera JJ, Thomason DN (1992) Zincphosphorus interaction in two cultivars of tomato grown in chelator-buffered nutrient solutions. Plant Soil 143:163-177

[10] Pikovaskya RI (1948). Mobilization of phosphorus in soil in connection with the vital activity of some microbial species. Microbiology. 7: 362-370(1948).

[11] Poonam S, Kumawat K. C., Sabhjeet C., Navprabhjot K., 2014. Assesment of Zinc solubilisation by Endophytic Bacteria in legume Rhizosphere. Indi. J. Appl. Res.

[12] Prveen K. G., Leo. D.A., Emmanuel, Suseelendra D., Hsan M., Shaik A., 2013. Prospective zinc solubilizing bacteria for enhanced Nutrient Uptake and Growth Promotion in maize (Zea mays L.)Inter J. Microbiol. Vol 2013

[13] Ramesh, A., Sharma, S. K., Sharma, M. P., Yadav, N., Joshi, O. P., 2014.Inoculation of zinc solubilizing Bacillusaryabhattai strains for improved growth, mobilizationand biofortification of zinc in soyabean and wheat cultivated in Vertisils of central India. Appl. Soil. Ecol.73:87-96.
[14]Reyes V.A. and Z. Valduz, (2006) Phosphate solubilizing micro-organisms isolated from the rhizospheric and bulk soils of colonizer plants at an abandoned rock phosphate mine. plant Soil 287:69-75

[15] Saravanan, V. S., Madhiyan, M., Thangaru, M., 2007. Solubilization of zinc compounds bythe diazotrophic,plant growth promoting bactreriumGlucanacetobacter diazotrophicus. Chemoshere 66:1794-98.

[16] Saravanan, VS; Subramoniam, SR; Raj, SA (2003).Assessing in vitro solubilization of different zinc solubilizing bacterial (ZBS) isolates. Brazil J Microbiol 34: 121-125

[17] Shahad,S., Ahmed, N., 2008. Effects of various parameters on the efficiency of zinc phosphate solubilisation byindigenious bacterial isolates. Afri. J. Biotechnol. 7(10):1543-49.

[18] Shruthi P. 2013. Studies on zinc solubilizing bacteria and their effecton growth and yield of Maize.

[19]Zarrin Fatima, M. Saleemi, Muhammad Zia, T. Sultan, M. Aslam, Riaz -Ur- Rehman and M. Fayyaz Chaudhary (2009). Antifungal activity of plant growthpromoting rhizobacteria isolates against Rhizoctonia solani in wheat. African Journal of Biotechnology, 8(2): 219-225.

\section{Author Profile}

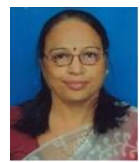

Dr. Pratibha B. Desai is the Director of Shree Ramkrishna Institute of Computer Education and Applied Sciences, Veer Narmad South Gujarat University, Surat, Gujarat (INDIA). She is also a member of Departmental Research Studies Committee for Bioscience Department of Veer Narmad South Gujarat University, Surat, Gujarat.

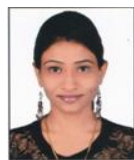

Kajal K. Ghevariya is a research scholar, reading for $\mathrm{Ph}$. D. in Microbiology under the guidance of Dr. Pratibha B. Desai, at Shree Ramkrishna Institute of Computer Education and Applied Sciences, Veer Narmad South Gujarat University, Surat, Gujarat 